\title{
TRIPLE-LAYER BASED CONTROL STRATEGY FOR MOLTEN CARBONATE Fuel CELL - HYBRID SYSTEM
}

\author{
Jarosław Milewski*, Andrzej Miller \\ Warsaw University of Technology, Institute of Heat Engineering, 21/25 Nowowiejska Street, \\ 00-665 Warsaw, Poland
}

\begin{abstract}
Based on mathematical modelling and numerical simulations, a control strategy for a Molten Carbonate Fuel Cell Hybrid System (MCFC-HS) is presented. Adequate maps of performances with three independent parameters are shown. The independent parameters are as follows: stack current, fuel mass flow and compressor outlet pressure. Those parameters can be controlled by external load, fuel valve and turbine-compressor shaft speed, respectively. The control system is purposed to meet many constraints: e.g. stack temperature, steam-to-carbon ratio, compressor surge limitation, etc. The aim is to achieve maximum efficiency of power generated within these constraints. Governing equations of MCFC-HS modelling are given. An operational line of the MCFC-GT system is presented which fulfils several constraints (temperature difference, cell temperature, etc.) The system is able to achieve efficiency of more than $62 \%$ even in part-load operation.
\end{abstract}

Keywords: control strategy, Solid Oxide Fuel Cell, off-design operation

\section{INTRODUCTION}

Presently, energy is produced by large stationary power plants and distributed to customers via a grid. In the future the energy distribution will probably take a radically different from - it will be composed of many small units connected to a network called distribution generation (DG).

DG is a system of energy distribution where the energy is produced locally. A connection to the grid allows energy to be bought from and sold to other customers. Energy sources for DG will have to meet certain requirements: appropriate range of power output, electric efficiency-which are higher than presently obtained by large power plants, acceptable costs of installation, possibility of utilisation of standard fuels.

Most of the requirements are met by fuel cells (Milewski et al., 2011a; 2011b) and fuel cell hybrid systems (HS). Molten Carbonate Fuel Cells (MCFCs) are potential sources of this system of energy conversion due to their high efficiency, possibilities of direct use of hydrocarbons. Moreover, their high working temperature allows for the possibility of using lower-cost catalysts ( $\mathrm{Ni} v \mathrm{vs}$. Pt) and the possibility of adding a gas turbine subsystem to increase total efficiency.

Control strategy is an important element in designing any system of this kind and it constituted a significant part of the modelling works done. Off-design (part-load) analysis is an important issue for any type of system involving MCFC-HS and should be taken into account when designing and defining operational characteristics. A proper off-design map of performance underscores control strategy design (Milewski et al., 2010). Results drawn from system behaviour analysis under part-load condition 
should aid in defining the system structure and its nominal parameters, as well as the constructional solution and characteristics of a given subsystem.

Off-design operation of a Solid Oxide Fuel Cell Hybrid System was analysed previously inter alia by Chan et al. (2002, 2003); Costagama et al. (2001); Freeh et al. (2005); Kimijima and Kasagi (2002); Marsano et al. (2004); Milewski et al. (2007); Miller et al. (2007); Palsson and Selimovic (2001); Stiller (2006); Stiller et al. (2005; 2006); Thorstensen (2001).

Far less work has been done on Molten Carbonate Fuel Cell Hybrid Systems. Bedont et al. (2003) investigated off-design performance of a hybrid system based on an existing $100 \mathrm{~kW}$ MCFC stack. Chen et al. (2006) show that the generating efficiency of the MCFC-HS $(\sim 13 \mathrm{~kW})$ is close to $60 \%$ at the design point and over $56 \%$ at part load conditions. A few dynamic response investigations of the MCFC can be found in He et al. (1998); Kang et al. (2001); Mangold et al. (2004); Sheng et al (2006).

In this control strategy study for MCFC-HS, the methodology and experience of the Institute of Heat Engineering (Warsaw University of Technology) were used. In particular, this methodology was utilised in the mathematical modelling of the "classic" system elements (e.g. compressor, turbine, heat exchanger). The HYSYS.Plant (1999) software was used for modelling and simulations.

Results presented in this paper concern a larger system (3 MW) which can be utilized for office building applications. An axial turbine can replace radial turbine for this range of power.

\section{MOLTEN CARBONATE FUEL CELL - GAS TURBINE HYBRID SYSTEM}

The Molten Carbonate Fuel Cell - Hybrid System consists of the following elements:

- air compressor,

- fuel compressor,

- gas turbine,

- air heater,

- fuel heater,

- MCFC module.

Based on 0D mathematical modelling the design point parameters of the system presented in Fig. 1 were estimated. The main system parameters are presented in Fig. 1 and Table 1.

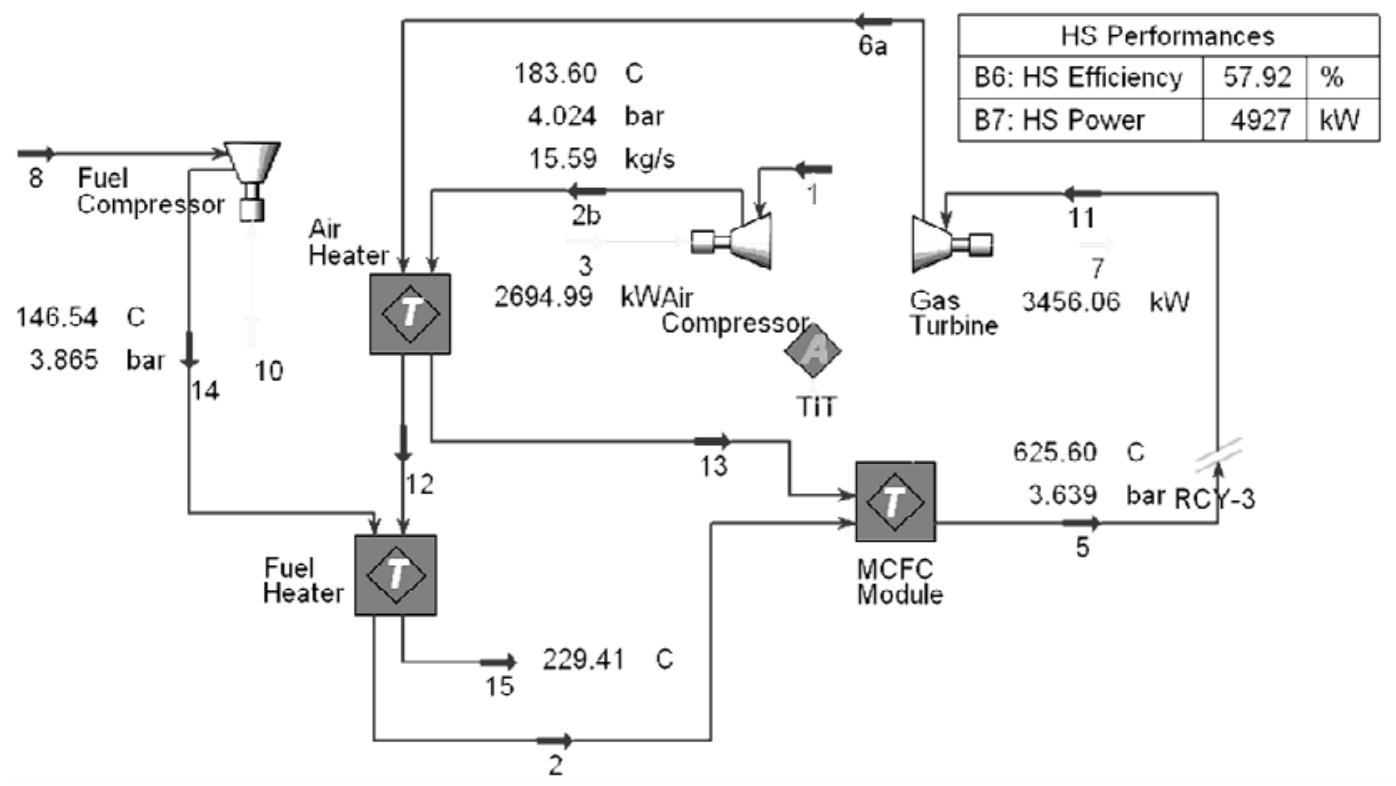

Fig. 1. The model of MCFC-HS created in HYSYS environment software 
Table 1. The main parameters of the reactors

\begin{tabular}{|l|c|}
\hline \multicolumn{1}{|c|}{ Parameter } & Value \\
\hline System efficiency (LHV), \% & 58 \\
\hline Re-cycle Factor, $\%$ & 44 \\
\hline Excess Air Factor & 1.68 \\
\hline Cell Voltage, $\mathrm{mV}$ & 659 \\
\hline DC/AC inwerter efficiency, $\%$ & 95 \\
\hline Electric generator efficiency, $\%$ & 99 \\
\hline Mechanical efficiency of the GT, $\%$ & 99 \\
\hline Electric motor efficiency, $\%$ & 95 \\
\hline Turbine Inlet Temperature, ${ }^{\circ} \mathrm{C}$ & 650 \\
\hline Electrolyte matrix thickness, $\mu \mathrm{m}$ & 1000 \\
\hline
\end{tabular}

The planar MCFC has pre-commercial applications (100 kW to $2 \mathrm{MW})$ which include the methanefuelled MCFC Module (MCFC-M) as the main object. The fuel cell stack, heat exchangers, mixing chamber, blower, pre-reforming plenum and re-cycle plenum are placed inside the MCFC-M.

The stack consists of parallel and series connected cells. A singular cell consists of three main layers: anode, electrolyte, and cathode. The electrolyte is kept by a matrix, which provides cell support.

Process air is delivered to the MCFC at an elevated temperature and flows through the heat exchanger. Air then flows through the stack and escapes on the other side. Finally, it enters the combustion plenum where the remaining non-oxidised components are utilised. Nominal parameters of the presented system are given in Table 1. They were obtained by the researchers' own calculations based on an adequate mathematical model (see Fig. 1). During the simulation the electrolyte matrix thickness and electrolyte materials assumed were of $1 \mathrm{~mm}$ and $\mathrm{Li} / \mathrm{Na}$, respectively.

Proper and efficient operation of the MCFC module requires additional devices.

Excess power from the compressor turbine subsystem is converted into electricity. HS efficiency is given by the equation:

$$
\eta_{H S}=\frac{P_{M C F C} \cdot \eta_{D C / A C}+\left(P_{T}-P_{C, \text { air }}\right) \cdot \eta_{g} \cdot \eta_{m}-\frac{P_{C, \text { fuel }}}{\eta_{e}}}{n_{\text {fuel }} \cdot H H V_{\text {fuel }}}
$$

where: $P_{M C F C}$ - electric power generated by MCFC Module, $n_{\text {fuel }}$ - fuel molar flow; $H H V_{f u e l}$ - High Heating Value of fuel; $P_{T}$-gas turbine power, $P_{C, a i r}-$ air compressor power; $P_{C, f u e l}-$ fuel compressor power; $\eta_{D C / A C}-\mathrm{DC} / \mathrm{AC}$ inverter efficiency; $\eta_{g}$ - electric generator efficiency; $\eta_{m}$ - mechanical efficiency of the GT; $\eta_{e}$ - electric motor efficiency.

\section{MATHEMATICAL MODEL OF THE SYSTEM}

Mathematical modelling is now the basic method for analysing systems incorporating fuel cells. A zero-dimensional approach is used for the modelling of system elements. 


\section{1. $M C F C$}

The presented results are based on calculations made using an appropriate mathematical model. The governing equations of this model are presented in this section.

An MCFC consists of series and parallel connected cells. Series connected cells make a stack. The electricity generated by an MCFC is given by the following equation (Milewski and Miller, 2006):

$$
P_{M C F C}=I \cdot E_{M C F C}
$$

where: $I$ - cell current; $E_{M C F C}$ - cell voltage.

The cell current $(I)$ is defined by the following equation:

$$
I=2 \cdot F \cdot n_{H_{2}, \text { equivalent,in }} \cdot \eta_{f}
$$

where: $F$ - Faraday's constant, $\mathrm{C} / \mathrm{mol} ; n_{H 2, \text { equivalent,in }}$ - equivalent hydrogen inlet molar flow, kmol/s; $E$ - cell voltage.

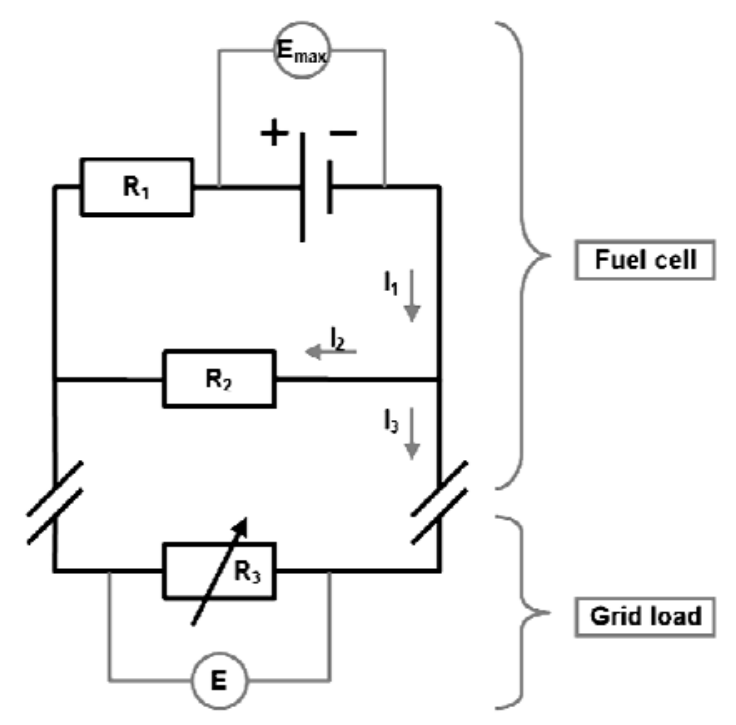

Fig. 2. Equivalent electric circuit of the cell (Milewski and Miller, 2006)

The equivalent electric circuit of a singular cell is shown in Fig. 2, (Milewski and Miller, 2006). Two types of resistance are present in fuel cells: ionic resistance $r_{1}$ and electric resistance $r_{2}$. Resistance $r_{3}$ is the external load resistance of the fuel cell and is varied by the operator of the MCFC. Voltage generated by a singular cell is given by the following equation (Milewski and Miller, 2006):

$$
E_{M C F C}=\frac{E_{\max }-\eta_{f} \cdot i_{\max } \cdot r_{1}}{\frac{r_{1}}{r_{2}} \cdot\left(1-\eta_{f}\right)+1}
$$

where: $E_{\max }$ - maximum voltage; $\eta_{f}$ - fuel utilization factor, Milewski et al. (2006); $i_{\max }$ - maximum current density; $r_{1}$ - internal ionic area specific resistance of the cell; $r_{2}$ - internal electronic area specific resistance of the cell.

The second type of internal resistance is electronic resistance $-r_{2}$ (see Fig. 2). The luence of temperature and matrix thickness on electronic internal resistance of electrolytes is not well known. The electronic conductivity values of molten carbonate electrolytes are probably spread across a very wide range. They do not have a major impact on calculated cell voltage for high fuel utilisation factors. It is difficult to measure the electronic resistance of molten carbonate electrolytes since they have both 
conductivities - ionic and electronic - simultaneously, which gives total electrical resistance. It should be noted that decreasing electrolyte matrix thickness reduces ionic resistance, but also probably reduces electronic resistance. Electronic resistance mainly influences Open Circuit Voltage (OCV).

The value of electronic resistance of the cell can be estimated from available experimental results. Substituting $\eta_{f}=0$ into Equation(4), the OCV can be defined by the following relationship:

$$
E_{O C V}=\frac{E_{\max }}{\frac{r_{1}}{r_{2}}+1}
$$

For given $r_{1}, E_{\max }$ and $E_{O C V}$ (from experimental measurements) the value of electronic conductivity of the cell can be found from the following relationship:

$$
\sigma_{2}=\delta \cdot \frac{E_{\max }-E_{O C V}}{r_{1} \cdot E_{O C V}}
$$

where: where: $\sigma_{2}$ - electronic conductivity of the electrolyte.

$$
r_{2}=\frac{\delta}{\sigma_{2}}
$$

The value of $\sigma_{2}=3.5 \cdot 10^{-3} \mathrm{~S} / \mathrm{cm}$, was taken from the researchers' own calculations, which were based on data presented by Arato et al. (2001). It was assumed that this value is independent of temperature. The thickness of electrolyte matrix was assumed $1 \mathrm{~mm}$. The $i_{\max }$ of $0.6 \mathrm{~A} / \mathrm{cm}^{2}$ was determined by the researchers' own calculations, which were based on data provided by Arato et al. (2001). If fuel cell area is fixed (off-design operation) the $i_{\max }$ value has to be calculated each time when inlet fuel flow is changed.

The maximum voltage of a singular cell is given by the following equation:

$$
E_{\max }=\frac{R T}{4 F} \ln \frac{p_{\mathrm{O}_{2} \text {,cathode }} \cdot p_{\mathrm{CO}_{2} \text {,cathode }}^{2}}{p_{\mathrm{O}_{2} \text {,anode }} \cdot p_{\mathrm{CO}_{2} \text {,anode }}^{2}}
$$

where: $T$-absolute temperature; $R$ - universal gas constant; $F$ - Faraday's constant; $p_{O 2, \text { cathode }}$ - oxygen partial pressure at cathode inlet; $p_{O 2, \text { anode }}$ - oxygen partial pressure at anode inlet; $p_{C O 2, \text { cathode }}$ - carbon dioxide partial pressure at cathode inlet; $p_{\mathrm{CO} 2 \text {,anode }}$ - carbon dioxide partial pressure at anode inlet.

Adequate partial pressures were calculated through the use of software. Those calculations are based on Peng-Robinson equation of the state and minimisation of Gibbs' free energy, HYSYS.Plant (1999).

The ionic resistance of molten carbonate electrolytes as a function of electrolyte temperature is shown in Fig. 3. This diagram contains values obtained by the researchers' own calculations, which were based on data published by Morita et al. (2002).

The internal area specific ionic resistance can be described by the following relationship:

$$
r_{1}=\frac{\delta}{\sigma}
$$

where: $\delta$ - electrolyte matrix thickness; $\sigma$ - ionic conductivity of molten carbonate.

The ionic conductivity of the carbonate is defined as follows:

$$
\sigma=\sigma_{0} \cdot e^{\frac{-E}{R T}}
$$

where: $\sigma_{0}, \mathrm{~S} / \mathrm{cm} ; E, \mathrm{~kJ} / \mathrm{mol}$, - factors depended on used carbonate. 


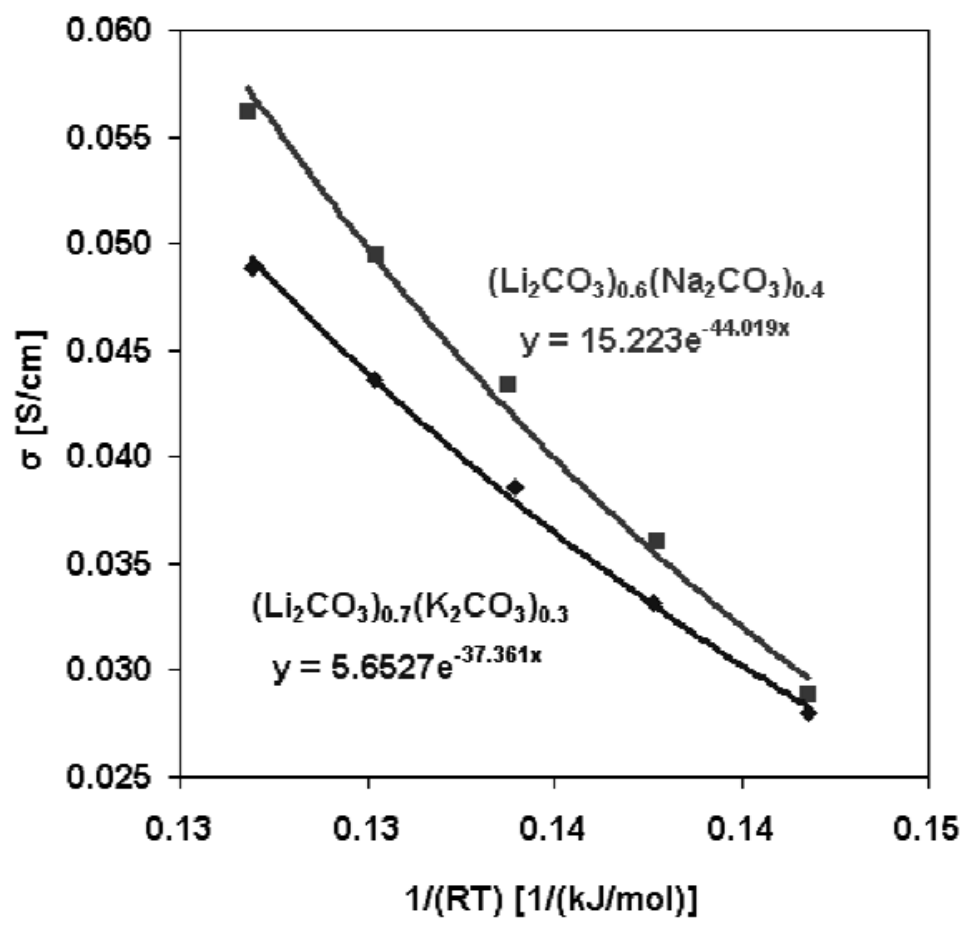

Fig. 3. Temperature dependence of ionic conductivity for molten carbonates (Milewski et al., 2007)

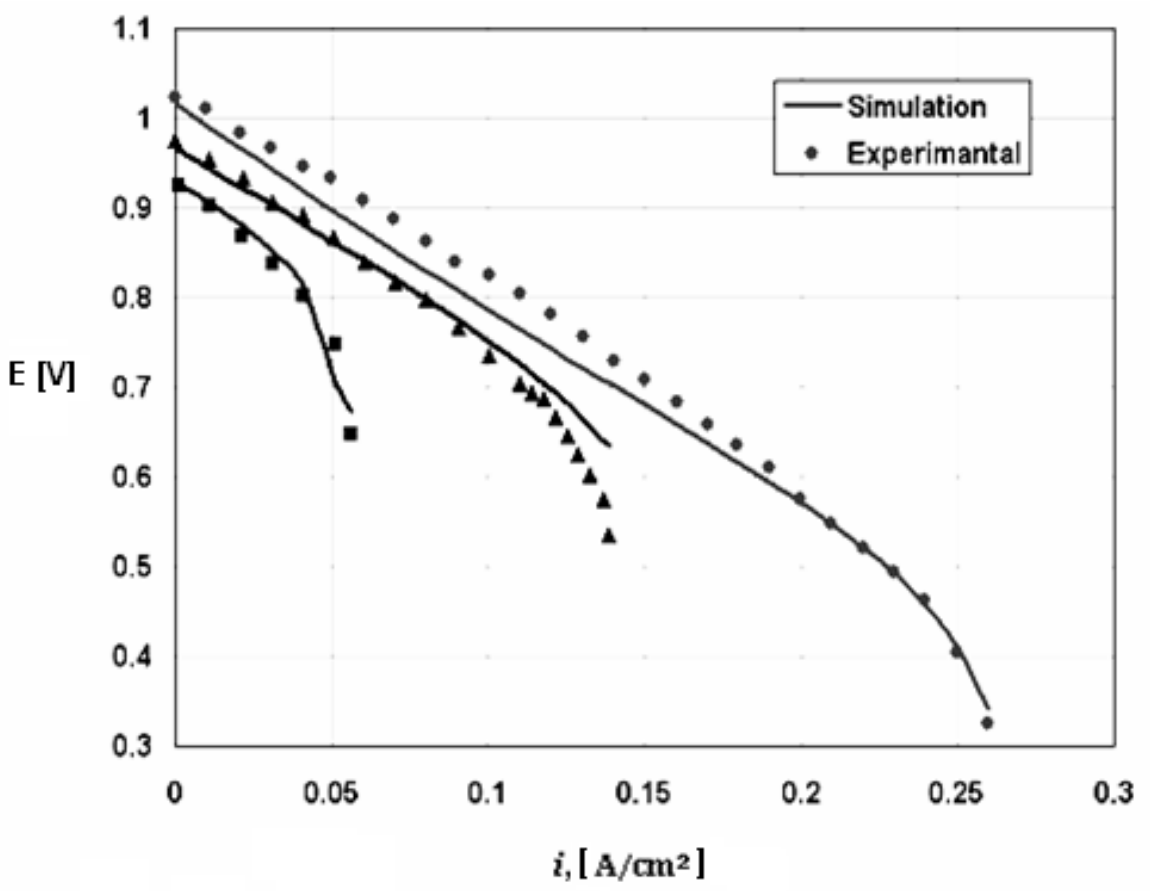

Fig. 4. Experimental (dots) and simulation (lines) data at different $\mathrm{H}_{2}$ molar fractions (Arato et al., 2001)

The presented model was compared with experimental data, this comparison is shown in Fig. 4. The area of the cell is fixed during off-design calculations, which means that factor $i_{\max }$ has to be calculated based on the following equations:

$$
i_{\max }=\frac{2 F n_{H_{2}, \text { equivalent }}}{A}
$$

where: $n_{H 2, \text { equivalent }}$ - equivalent hydrogen molar flow at anode inlet. 
The equivalent hydrogen molar flow at anode inlet is defined by the following relationship:

$$
n_{\mathrm{H}_{2}, \text { equivalent }}=n_{\mathrm{H}_{2}}+4 \cdot n_{\mathrm{CH}_{4}}+n_{\mathrm{CO}}
$$

where: $n_{H 2}$ - hydrogen molar flow at anode inlet; $n_{C H 4}-$ methane molar flow at anode inlet; $n_{\mathrm{CO}}-$ carbon monoxide molar flow at anode inlet

\subsection{Air Compressor}

Compressor performance during off-design operation was calculated through the use of an appropriate map. The compressor map gives the following relationships: $\bar{\Pi}, \bar{\eta}=f(\bar{m}, \bar{n})$.

Rad. Compr. PIP=5.5 AIAA 79-1159

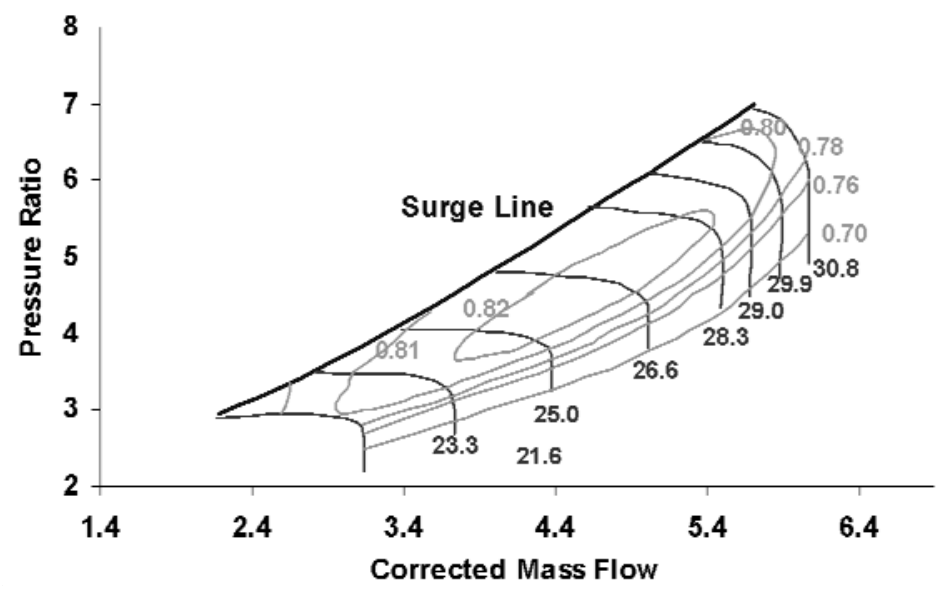

Fig. 5. Air compressor map (Kurzke and Riegler, 2000)

Kurzke and Riegler (2000) provided a valuable method for compressor map evaluation in the preliminary conceptional design phase of a gas turbine. The method is soundly based on experimental data. The map utilised for our case is shown in Fig. 5. The off-design performance of the fuel compressor is neglected from the whole system point of view.

\subsection{Gas Turbine}

The turbine model in question is reduced to a model of the turbine stage group. Two essential characteristics are needed here: flow capacity and efficiency changes under variable operating conditions. In contradistinction to compressors it is possible here to find analytical descriptions of characteristics (Miller and Lewandowski, 1992; Trzcinska et al., 1997).

The following equation describes the flow capacity:

$$
\frac{m}{m_{o}}=A \cdot \frac{p_{\alpha}}{p_{\alpha, o}} \sqrt{\frac{T_{\alpha, o}}{T_{\alpha}}} \frac{E}{E_{o}}
$$

where: $m$ - mass flow rate; $p_{\alpha}, T_{\alpha}$ - inlet gas parameters; $A=f(\bar{n})$-coefficient; $\bar{n}=\frac{n}{n_{o}} \sqrt{\frac{T_{\alpha, o}}{T_{\alpha}}}$; $n$-nominal rotational shaft speed; $E=\sqrt{1-\left(\frac{\Pi-\beta \cdot B}{1-\beta \cdot B}\right)^{2}} ; \Pi=\frac{p_{\omega}}{p_{\alpha}}$-turbine pressure ratio; $\beta$ - critical pressure ratio of turbine stage group; $B=f(\bar{n})$ - coefficient; $o$ - denotes a design-point value. 
In the analysed case, $\beta \approx 0$ due to a small value of $\Pi_{\mathrm{o}}$ and the flow capacity equation takes the form:

$$
\frac{m}{m_{o}}=A \cdot \frac{p_{\alpha}}{p_{\alpha, o}} \sqrt{\frac{T_{\alpha, o}}{T_{\alpha}}} \sqrt{\frac{1-\Pi^{2}}{1-\Pi_{o}^{2}}}
$$

where coefficient

is shown in Fig. 4.

The turbine efficiency under off-design is given by set of relations (Miller and Lewandowski, 1992; Trzcinska et al., 1997):

$$
\begin{gathered}
\bar{n}=\frac{n}{n_{o}} \cdot \sqrt{\frac{j_{\alpha o}}{j_{\alpha}}} \\
\sqrt{\frac{j_{\alpha o}}{j_{\alpha}}} \approx \sqrt{\frac{T_{\alpha o}}{T_{\alpha}}} \\
\bar{\eta}=\frac{\eta}{\eta_{o}} \\
\overline{\bar{n}}=\frac{\bar{n}}{\bar{n}_{\text {opt }}} \\
\overline{\bar{\eta}}=\frac{\bar{\eta}}{\bar{\eta}_{\max }} \quad \text { for } \quad \overline{\bar{n}}<1 \\
\overline{\bar{\eta}}=1-(1-\overline{\bar{n}})^{a_{1}} \quad \text { for } \quad \overline{\bar{n}} \geq 1 \\
\overline{\bar{\eta}}=1-a_{3}(1-\overline{\bar{n}})^{a_{2}} \quad \text { f }
\end{gathered}
$$

For the analysed case: $a_{1}=4.3, a_{2}=1.7, a_{3}=0.14$.
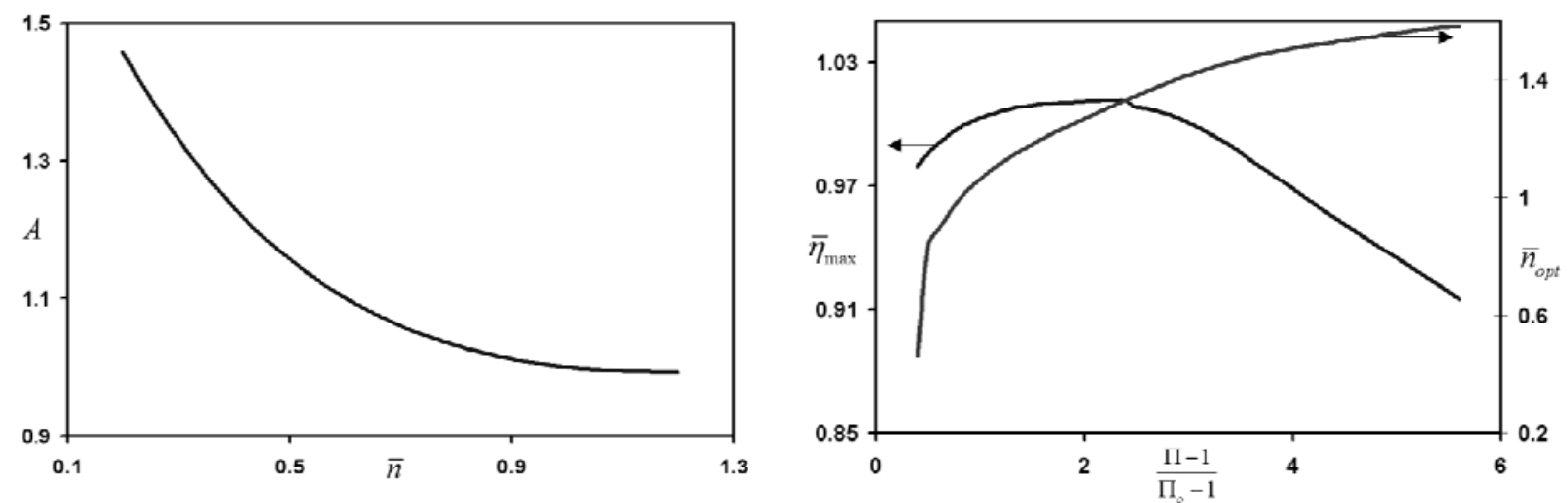

Fig. 6. The coefficient of A and the reduced maximum efficiency and reduced optimum rotational

The reduced maximum turbine efficiency and reduced optimum rotational speeds are shown in Fig. 6.

\subsection{Other system elements}

Other system elements (e.g. heat exchangers) were modelled based on software procedures or the methodology and experience of the Institute of Heat Engineering at Warsaw University of Technology.

Methane is mixed with steam to avoid a carbon deposition. It was assumed that an adequate steam-tocarbon ratio to prevent carbon deposition was 1.4 (Van Herle et al., 2004). The steam-to-carbon ratio 
(s/c ratio) defines steam molar flow in relation to methane and carbon monoxide molar flows delivered to the reformer.

$$
s / c=\frac{n_{\mathrm{H}_{2} \mathrm{O}}}{n_{\mathrm{CH}_{4}}+n_{\mathrm{CO}}}
$$

where: $n$ - molar flow, kmol/s; $\mathrm{H}_{2} \mathrm{O}$ - steam; $\mathrm{CO}$ - carbon oxide; $\mathrm{CH}_{4}$ - methane.

\section{MAPS OF PERFORMANCE}

Part-load operation characteristics research regarding MCFC-HS can be reduced mainly to study of the conditions of co-operation among the MCFC, turbo machines and other equipment. A specific feature of this study is the existence of many bonds and limits. Bonds are defined mainly by the system configuration and properties of devices that make up the system, together with their characteristics. Limits usually result from boundary values of working parameters. Thus, studying the conditions of cooperation of the MCFC-HS can be reduced to describing and analysing all the possible operational stages. Part-load and over-load performance characteristics of MCFC-HS were calculated and analysed to show control possibilities of the cycle.

The MCFC-HS operator can control the following input parameters:

- fuel mass flow by a methane valve,

- MCFC current by external resistance,

- rotational speed of the compressor-turbine subsystem by a special electric generator.

The responses of MCFC-HS to these three main parameters were investigated. Calculations revealed the working conditions of the MCFC-HS in off-design operation to be over a few thousand different points in relation to its design point. This collection of data is extremely large and difficult to analyse. Adequate maps of parameter changes were constructed to present the most important results. Those maps contain data for the constant fuel utilisation factor.

\section{DISCUSSION}

In general it should be underlined that in the case of a system with a pressurise MCFC and gas turbine set there is a possibility of changing the system power output by changing not only the fuel amount but also the voltage and the MCFC current at variable rotational speeds of the compressor-turbine unit. This is accompanied by varying system efficiencies. Hence there is a need to formulate an appropriate control concept (control strategy logic) and attempt its technical realisation.

A triple layer control system is proposed for MCFC-HS operation controlling. The system consists of three layers: Control Strategy, Adaptation, and Regulation (Fig. 8).

The first layer is responsible for safe and efficient operation of the whole hybrid system. Adequate functional relationships between all the controlled parameters and constraints should be applied. The adaptation layer is responsible for making corrections to the first layer characteristics due to degradation of the system elements. The last layer of the control system acts in dynamic mode to realise the control strategy.

The control strategy is based on three functional relationships:

$$
m_{\text {Fuel }}=f\left(P_{H S}\right)
$$




$$
\begin{gathered}
n=f\left(P_{H S}\right) \\
I_{M C F C}=f\left(P_{H S}\right)
\end{gathered}
$$

where: $P_{H S}-$ is power demanded by external load.

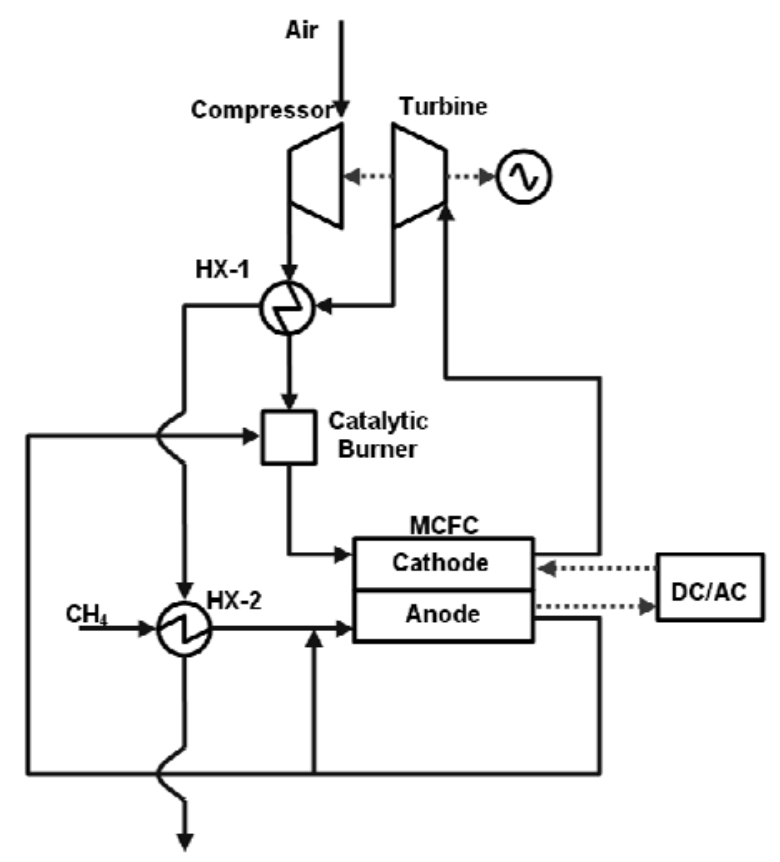

Fig. 7. MCFC Hybrid System

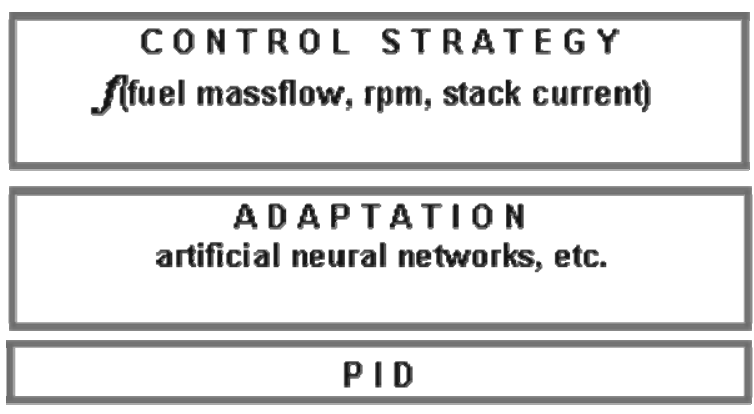

Fig. 8. Triple layer control system

Approximately, 16000 system operation points (state points) were found. Every state point is defined by three independent parameters: delivered fuel flow, rotational speed of compressor-turbine subsystem, and stack current. The other flow and electric parameters were collected for these three parameters. This data set was analysed and it was found that the best system performance is obtained at the highest values of fuel utilisation factor (see Fig. 9).

The highest possible fuel utilisation factor was found to be $90 \%$. It means that fuel flow can be correlated with the used electric current from the stack by the following relationships:

$$
\begin{gathered}
\frac{I}{m_{\text {Fuel }}}=\text { const } \\
\frac{I_{\text {stack }}}{I_{\text {stack, } \max }}=a \cdot P_{M C F C-H S}+b
\end{gathered}
$$




$$
\frac{m_{f u e l}}{m_{f u e l, \max }}=a \cdot P_{M C F C-H S}+b
$$

where: $a$ and $b$ - linear regression factors.

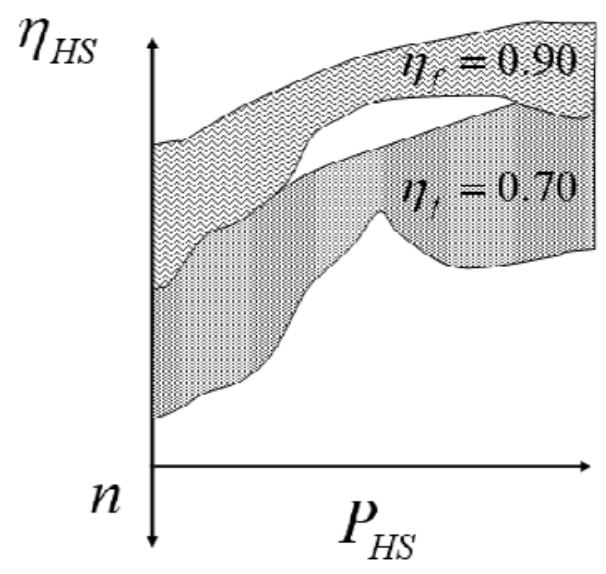

Fig. 9. MCFC-HS efficiency layers for two different fuel utilisation factors

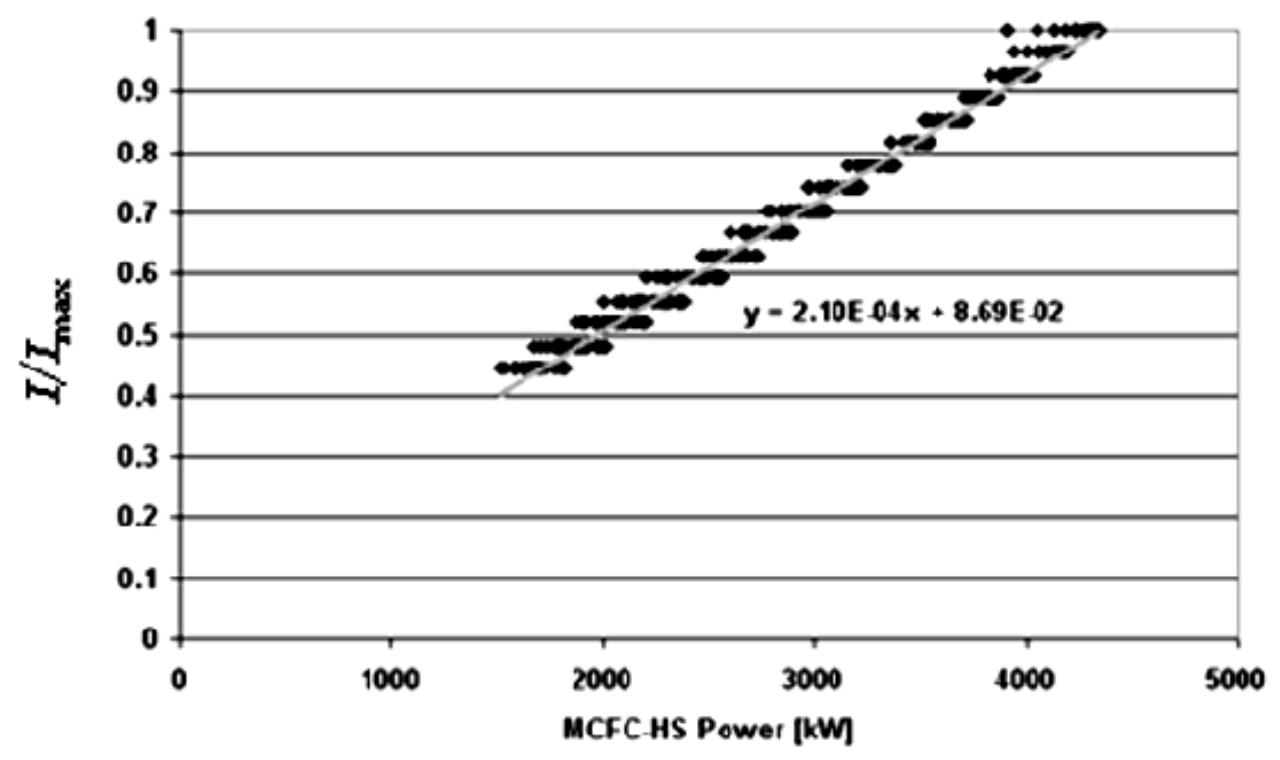

Fig. 10. Dependence of stack current and fuel mass flow on hybrid system power

The linear regression factors $a$ and $b$ are: $2.1 \cdot 10^{-4}$ and $8.69 \cdot 10^{-2}$ (see Fig. 10). The maps presented below include the values of parameters for constant fuel utilisation factor of $90 \%$.

There are several factors which are very important for keeping a system in a safe mode. The most important one is temperature. Two temperatures were taken into consideration as constraints in the system operation: stack temperature difference and entire fuel cell temperature. Additionally, the gas turbine is also limited by TIT (Turbine Inlet Temperature) which depends mainly on turbine size (smaller turbines are built with non-cooled blades---thus the available temperature should not be higher than about $900^{\circ} \mathrm{C}$ ). All those limits were taken into consideration when the operational line of the control system was determined (see Fig. 15). 


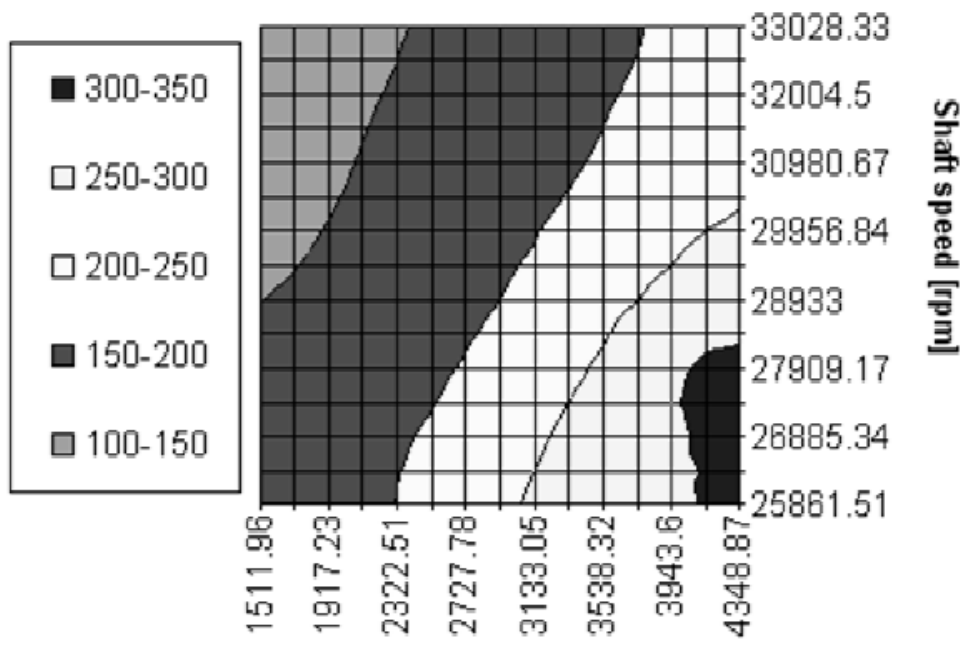

HS Power [kW]

Fig. 11. Stack temperature difference $\left({ }^{\circ} \mathrm{C}\right)$ for $\eta_{f}=0.9$

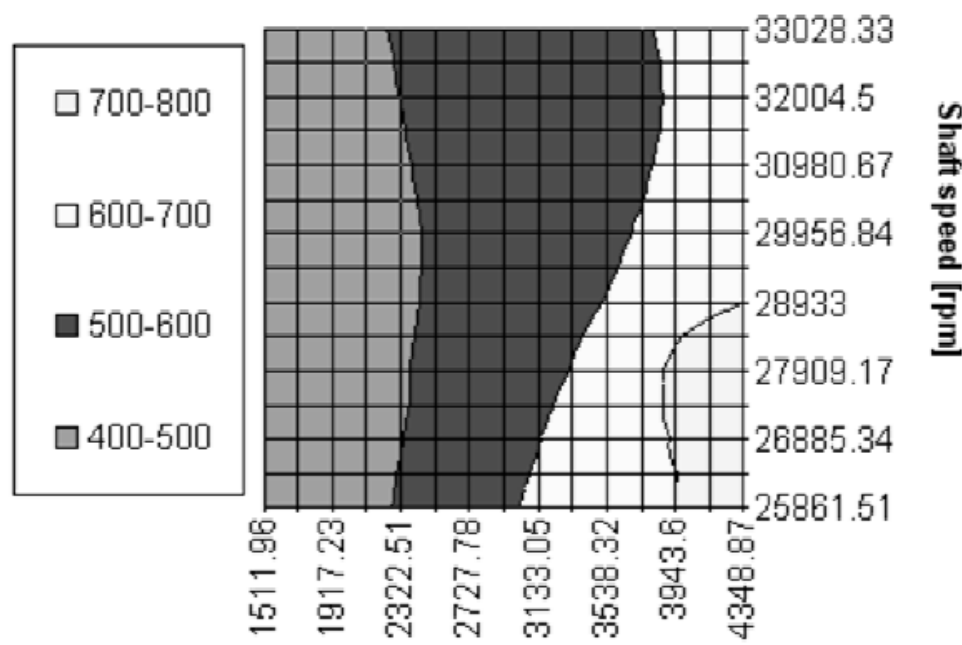

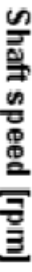

Fig. 12. Turbine Inlet Temperature $\left({ }^{\circ} \mathrm{C}\right)$ for $\eta_{f}=0.9$

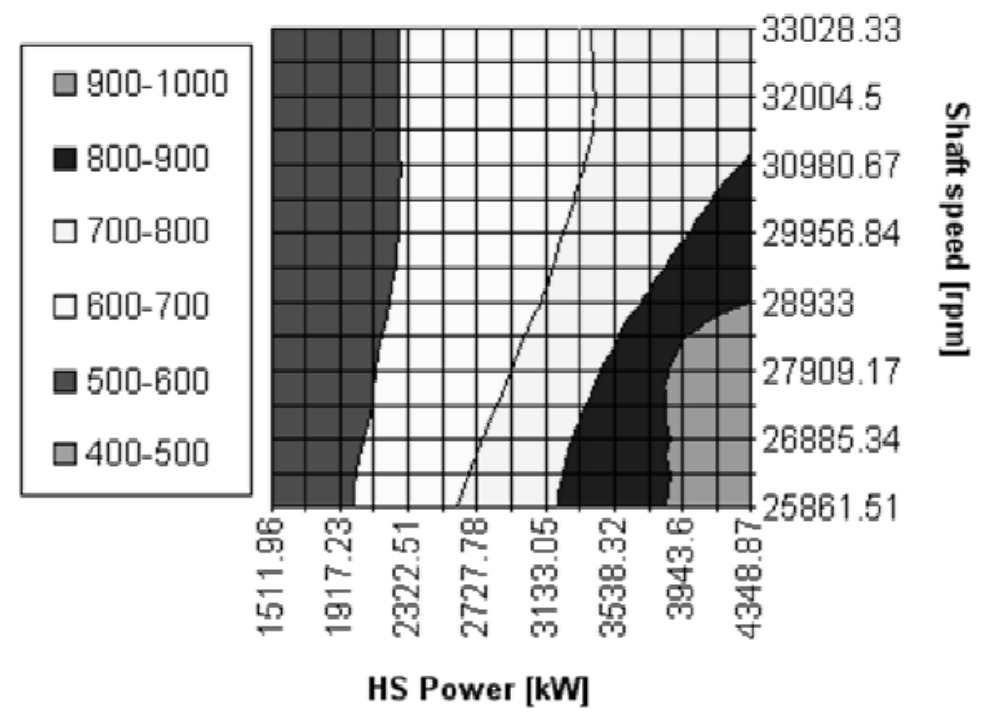

Fig. 13. Cell Temperature $\left({ }^{\circ} \mathrm{C}\right)$ for $\eta_{f}=0.9$ 
Fig. 11 presents a map of performance which indicates stack temperature difference (between stack inlet and outlet streams) for a constant fuel utilisation factor of $90 \%$. It can be seen that there are regions where the difference is larger than $300^{\circ} \mathrm{C}$ in the cases for which there is too small an amount of air delivered by the air compressor (for low rotational speeds of the GT shaft).

Turbine Inlet Temperature (TIT) is a crucial parameter for safe operation of the GT subsystem. In the analysed system, the turbine with non-cooled blades was assumed, meaning that TIT should not be more than $800^{\circ} \mathrm{C}$; fortunately nowhere in the indicated range does the temperature exceed this limitation, which means that the gas turbine subsystem does not limit the whole system operation.

Molten Carbonate Fuel Cells are designed for operation at $650^{\circ} \mathrm{C}$, which is related to molten carbonate conductivity characteristics (they become liquid above $550^{\circ} \mathrm{C}$ ). In fact, during the investigation, it was assumed that temperature was limited to $800^{\circ} \mathrm{C}$ for material reasons. In Fig. 13 it can be seen that this limitation is a crucial one, as too small an amount of coolant (air supplied by a compressor) allows the temperature to rise substantially in excess $800^{\circ} \mathrm{C}$.

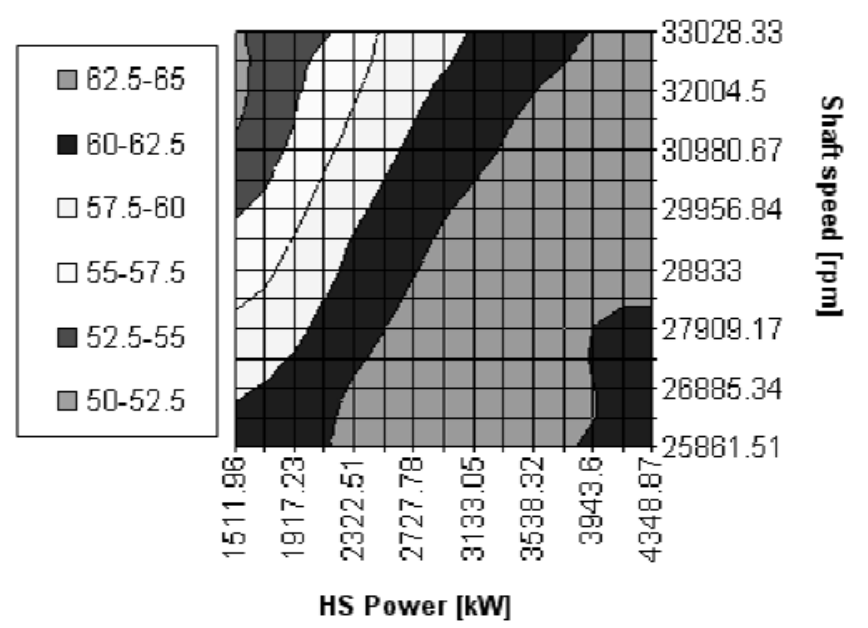

Fig. 14. Hybrid System Efficiency (\%) for $\eta_{f}=0.9$

The efficiency values of the system for all the points gathered during the simulations are mapped out in Fig. 14. It can be seen that the range with the highest efficiency occupies quite a large area of the map. This means that the MCFC-GT system has a favorable characteristic and that efficiency can be kept at very high values for a large operational region.

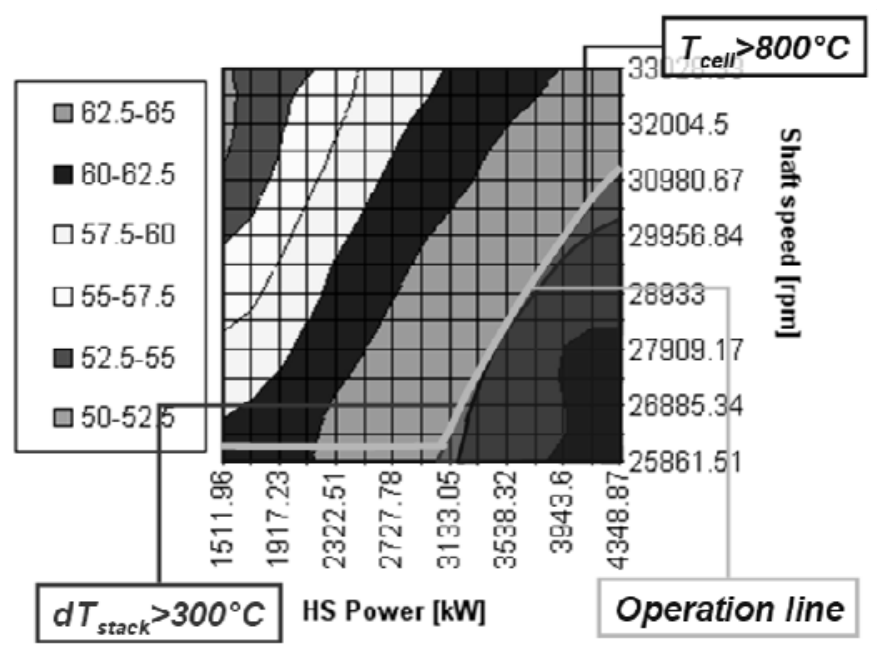

Fig. 15. MCFC-HS efficiency chart, main limitations and operation line are indicated 
The limitation and constraints mentioned above are shown in Fig. 15 as the limiting lines. Taking into account the criterion of the highest possible efficiency the operational line of the MCFC-GT system is obtained.

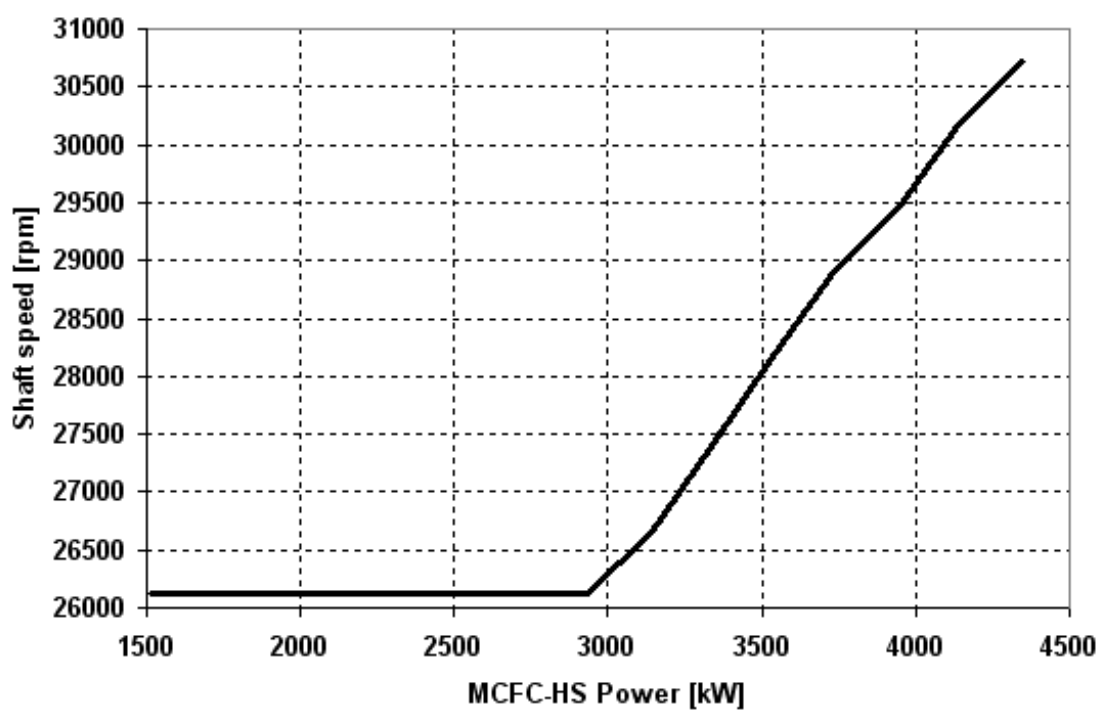

Fig. 16. Shaft speed as a function of MCFC-HS Power

Based on the obtained operational line, the separate operational characteristic of the GT subsystem can be found. The characteristic is shown in Fig. 16. The rotational speed decreases until about $3 \mathrm{MW}$ of total power, and from this point remains constant.

\section{CONCLUSIONS}

The presented results indicate that the analysed MCFC-HS possesses a high operation and control flexibility while at the same time maintaining stable thermal efficiency. Operation of the system is possible over a wide range of parameter changes. The control strategy given by operation line was indicated.

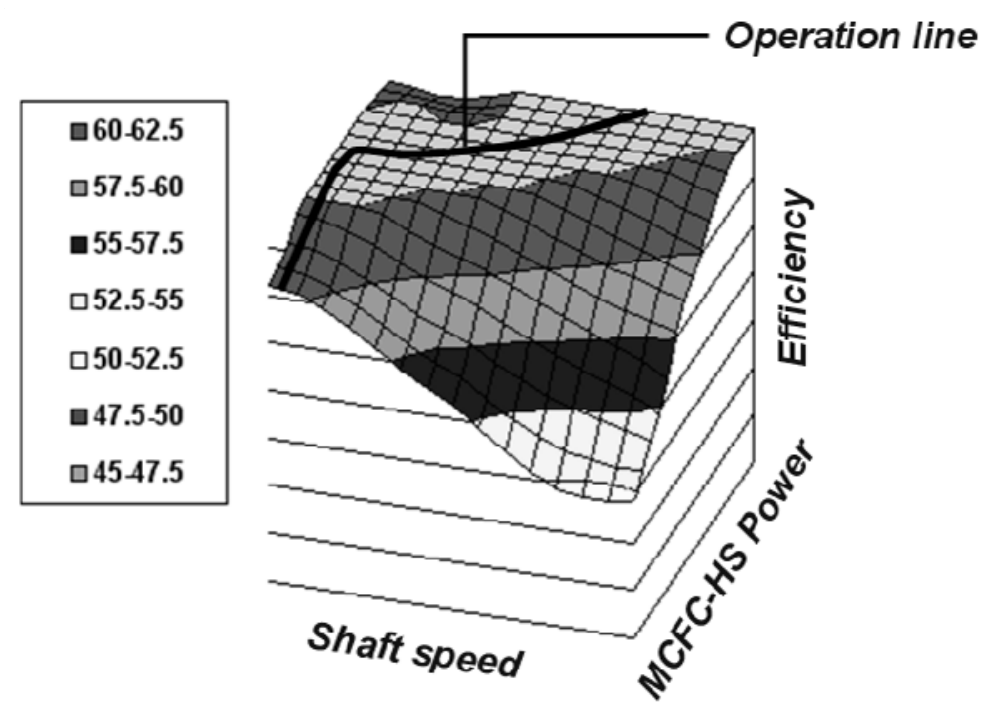

Fig. 17. Operation line of MCFC Hybrid System 
A triple-layer control system is proposed. Adequate maps of performance were generated by a MCFCHS simulator using 0D mathematical modelling. The operation line of MCFC-HS was determined based on an in-depth analysis of the obtained maps. The best performance and safe operation of the system can be achieved with constant fuel utilisation factor (at the highest possible value). Setting the constant fuel utilisation factor at 90\% appears acceptable and adequate relationships are proposed ((27) and (28)). The system can be kept within safe ranges by controlling the compressor-turbine shaft speed (see Fig. 16).

The stand alone MCFC unit is influenced by only few variables: an external power and ambient conditions. As far as the unit must meet the external power, the control system must keep crucial parameters in save operation ranges, which mainly means keeping fuel flow at set value according to the chosen fuel utilisation factor and air blow to cool the stack. On a contrary, in the case of a hybrid system, an additional degree of freedom is available: a division of generated power between MCFC stack and gas turbine subsystem. Additionally, both systems influence each other (e.g. stack temperature vs. Turbine Inlet Temperature) which needed to be managed.

The efficiency of the hybrid system is higher than that of MCFC-stand alone unit for two main reasons: firstly, a depleted heat from MCFC stack is utilised by the gas turbine system; secondly an increase of pressure raises a fuel cell efficiency. The MCFC stand alone unit can reach the efficiency up to $50 \%$, whereas a hybrid system can achieve more than $62 \%$. It should be noted that nowadays the highest possible efficiency is obtained by Gas Turbine Combined Cycles (GTCC) and equals 60\% for very high TIT of $1500^{\circ} \mathrm{C}$, which makes MCFC-GT systems very competitive.

\section{SYMBOLS}

$\begin{array}{ll}B & \text { coefficient, } \\ D G & \text { Distributed Generation, } \\ E & \text { Voltage, V; activation energy, } \mathrm{J} / \mathrm{mol} \text {; coefficient, } \\ F & \text { Faraday constant, } 96500 \mathrm{C} / \mathrm{mol}, \\ G T & \text { Gas Turbine, } \\ H H V & \text { Higher Heating Value, } \\ H S & \text { Hybrid System, } \\ I & \text { electric current, A } \\ i & \text { current density, A/cm }{ }^{2} \\ J & \text { technical enthalpy, } \mathrm{kJ} / \mathrm{kg} \\ M & \text { mass flow, kg/s } \\ M C F C & \text { Molten Carbonate Fuel Cell, } \\ N & \text { molar flow, kmol } / \mathrm{s} ; \text { rotational speed, } \mathrm{rpm} \\ O C V & \text { Open Circuit Voltage, } \\ P & \text { power, } \mathrm{kW} \\ P & \text { partial pressure, bar } \\ r & \text { area specific internal resistance, } \mathrm{cm}^{2} / \mathrm{S} \\ R & \text { ideal gas constant, } 8.315 \mathrm{~kJ} /(\mathrm{kmolK}) \\ S O F C & \text { Solid Oxide Fuel Cell, } \\ T & \text { absolute temperature, } \mathrm{K}\end{array}$

Greek symbols

$\begin{array}{ll}\beta & \text { critical pressure ratio } \\ \delta & \text { thickness, } \mu \mathrm{m} \\ \eta & \text { efficiency, fuel utilization factor } \\ \sigma & \text { conductivity, } \mathrm{S} / \mathrm{cm}\end{array}$




\section{REFERENCES}

Arato E., Bosio B., Costa P., Parodi F., 2001. Preliminary experimental and theoretical analysis of limit performance of molten carbonate fuel cells. J. Power Sources, 102, 74-81. DOI: 10.1016/S0378-7753(01)007972.

Bedont P., Grillo O., Massardo A.F., 2002. Off-design performance analysis of a hybrid system based on an existing molten fuel cell stack. ASME Conference Proceedings, 2, Turbo Expo 2002, Parts A and B, Paper no. GT2002-30115, 387-395. DOI: 10.1115/GT2002-30115.

Chan S.H., Ho H.K., Tian Y., 2002. Modeling of simple hybrid solid oxide fuel cell and gas turbine power plant. J. Power Sources.109, 111-120. DOI: 10.1016/S0378-7753(02)00051-4.

Chan S.H., Ho H.K., Tian Y., 2003. Multi-level modeling of SOFC-gas turbine hybrid system. Int. J. Hydrogen Energy, 28, 889-900. DOI: 10.1016/S0360-3199(02)00160-X.

Chen Q., Weng Y., Zhu X., Weng S., 2006. Design and partial load performance of a hybrid system based on a Molten Carbonate Fuel Cell and a gas turbine. Fuel Cells, 6, 460-465. DOI: 10.1002/fuce.200500228.

Costamagna P., Magistri L.,F. Massardo A., 2001. Design and part-load performance of a hybrid system based on a solid oxide fuel cell reactor and a micro gas turbine. J. Power Sources, 96, 352-368. DOI: 10.1016/S03787753(00)00668-6.

Freeh J.E., Steffen C.J., Larosiliere L.M., 2005. Off-design performance analysis of a solid-oxide fuel cell/gas turbine hybrid for auxiliary aerospace Power. Third International Conference on Fuel Cell Science Engineering and Technology. Ypsilanti, Michigan, USA, May 23-25, 2005.

He W., 1998. Dynamic model for molten carbonate fuel-cell power-generation systems. Energy Convert. Mgmt, 39, 775-783. DOI: 10.1016/S0196-8904(97)10022-X.

HYSYS. Plant 2.1 user guide, Hyprotech Corporation, 1999.

Kang B.S., Koh J-H., Lim H.C., 2001. Experimental study on the dynamic characteristics of kW-scale molten carbonate fuel cell systems. J. Power Sources, 94, 51-62. DOI: 10.1016/S0378-7753(00)00606-6.

Kimjima S., Kasagi N., 2002, Performance evaluation of gas turbine-fuel cell hybrid micro generation system. ASME Conference Proceedings, 2, Turbo Expo 2002, Parts A and B, Paper no. GT2002-30109, 333-340. DOI: 10.1115/GT2002-30109.

Mangold M., Sheng M., Heidebrecht P., Kienle A., Sundmacher K., 2004. Development of physical models for the process control of a molten carbonate fuel cell system. Chem. Eng. Sci., 59, DOI:4847-4852. DOI: 10.1016/j.ces.2004.08.019.

Marsano F., Magistri L., Massardo A.F., 2004. Ejector performance influence on a solid oxide fuel cell anodic recirculation system. J. Power Sources, 129, 216-228. DOI: 10.1016/j.jpowsour.2003.11.034.

Milewski J., Miller A., 2006. Influences of the type and thickness of electrolyte on solid oxide fuel cell hybrid system performance. J. Fuel Cell Sci. Technol., 3, 396-402. DOI: 10.1115/1.2349519.

Milewski J., Miller A., Salacinski J., 2007. Off-design analysis of SOFC hybrid system. Int. J. Hydrogen Energy, 32, 687-698. DOI: 10.1016/j.ijhydene.2006.08.007.

Milewski J., Badyda K., Misztal Z., Wołowicz M., 2011a. Combined heat and power unit based on polymeric electrolyte membrane fuel cell in a hotel application. Rynek Energii, 90, 118-123.

Milewski J., Badyda K., Misztal Z., Wołowicz M., 2011b. Operational characteristics of 36kW PEMFC-CHP Unit. Rynek Energii, 92, 150-156.

Miller A., J. Milewski, J. Salacinski, 2007. Off-design operation of fuel cell - gas turbine hybrid system. $7 t h$ European Conference on Turbomachinery, Athens, Greece, 5-9 March 2007.

Palsson J., Selimovic A., 2001, Design and off-design predictions of a combined SOFC and gas turbine system, Proceedings of ASME TURBO EXPO. New Orleans, USA, June 4-7, 2001.

Sheng M., Mangold M., Kienle A., 2006. A strategy for the spatial temperature control of a molten carbonate fuel cell system. J. Power Sources, 162, 1213-1219. DOI: 10.1016/j.jpowsour.2006.08.025

Stiller C., 2006. Design, operation and control modeling of SOFC/GT Hybrid Systems. PhD dissertation, Norwegian University of Science and Technology.

Stiller C., Thorud B., Bolland O., 2005. Safe dynamic operation of a simple SOFC/GT hybrid system. ASME Turbo Expo 2005: Power for Land, Sea and Air. Reno-Tahoe, Nevada, USA, June 6-9, 2005, GT2005-68481.

Stiller C., Thorud B., Bolland O., Kandepu R., Imsland L., 2006. Control strategy for a solid oxide fuel cell and gas turbine hybrid system. J. Power Sources, 158, 303-315. DOI: 10.1016/j.jpowsour.2005.09.010. 
Thorstensen B., 2001. A parametric study of fuel cell system efficiency under full and part load operation, J. Power Sources, 92, 9-16. DOI: 10.1016/S0378-7753(00)00497-3.

Trzcinska Z., Miller A., Lewandowski J., 1997. Performance characteristic of reaction type turbine stage groups. Proceedings of the 2nd European Conference on Turbomachinery - Fluid Dynamics and Thermodynamics. Antwerpen, Belgium, March 5-7, 1997.

Van herle J., Maréchal F., Leuenberger S., Membrez Y., Bucheli O., Favrat D., 2004. Process flow model of solid oxide fuel cell system supplied with sewage biogas. J. Power Sources, 131, 127-141. DOI: 10.1016/j.jpowsour.2004.01.013. 